\title{
Knowledge Management as a Business Strategy of a Learning Organisation
}

\author{
Andreja Rudančić ${ }^{*}$ Petar Mišević, Dušan Tomašević
}

\begin{abstract}
Today, knowledge management is used as part of a business strategy by which an organisation adapts to rapid changes in society and the business world, by which it not only becomes more competitive but also achieves goals and remains successful. Organisations have become aware of the importance of the lifelong learning concept. It should be noted that knowledge management is in close synergy with human resource management in the organisation. To achieve the scientific value of the paper, the authors have conducted empirical research by using a survey questionnaire in which the elements of a learning organisation were investigated, along with the implementation of knowledge on the selected organisational model. The synthesis of the results and conclusions of this research will be used to formulate specific critical recommendations and valuable guidelines indicating possible areas of improving the level of learning organisation and motivation to learn, which indicates potential ways and approaches to knowledge management.
\end{abstract}

Keywords: business strategy; HR; knowledge; knowledge management; learning organisation

\section{INTRODUCTION}

Globalisation and modern market trends have led to rapid changes and innovations in the market, which in turn has resulted in a higher standard of competitiveness. Products have a shorter life cycle, individualisation of customer needs is required, new business areas are created, and companies that want to be competitive must quickly follow trends and improve their business. Companies today, if they aim to operate successfully and competitively, must know how to use knowledge as a factor of production. Otherwise, they risk falling behind in a turbulent business arena. Knowledge is predominantly linked to the people who make up an organisation, so it is difficult to observe it outside the context in which it was created. It consists of patents, processes, technology, capabilities, skills, information, and other. It is important to emphasise that knowledge management does not represent just companies' internal resources, but also includes customers, suppliers, contractual partners and further external know-how holders. Some companies have begun to measure knowledge in the form of intellectual capital, and all this leads to such a practice becoming quite ordinary and necessary in modern management.

\section{HISTORICAL FRAMEWORK OF UNDERSTANDING KNOWLEDGDE MANAGEMENT}

The idea of organisational learning and knowledge has long been present in the literature, but it was not until the 1930 s that the first significant work on organisational learning appeared. In the 1970s, there was more productive academic work on this topic, and since then, interest in this topic has increased exponentially [1]. Since the early 1990s, knowledge management has become widely known, and many authors believe that the idea an organisation that learns and possesses knowledge as a resource one of the most significant contributions to management theory in the last half-century. According to [2], the transformation into a global information and knowledge society is confirmed by the notion of Kondratieff's fifth cycle. Kondratieff found that the economic development of nations can be described in periods of 40 to 60 years, and critical innovations are usually the drivers of each period. Prosperity, recession, depression and recovery always follow one another.

The first half of the $19^{\text {th }}$ century was marked by the discovery of the stationary power of steam, which started the industrial revolution. The second wave began in the middle of the $19^{\text {th }}$ century and lasted to its end. It was caused by the know-how about the power of steam and steel. Kondratieff's third cycle began in the early $20^{\text {th }}$ century and lasted until the outbreak of World War II. That period was based on knowledge of chemistry and electricity, and the fundamental innovation was the automobile. 1945 was followed by a fourth wave that brought television and mass traffic. It was the beginning of a developed world economy with mass production and high growth in labour productivity with high consumption of energy and raw materials. Many signs hint at the arrival of a new wave, the fifth Kondratieff cycle. North holds that labour and capital are no longer scarce resources, but information from which knowledge is generated [2]. Tangible goods are losing on their importance compared to intangibles, and investors are less and less appreciative of how physical products are made from physical resources, and more and more about how knowledge is accumulated from information and how that knowledge is turned into business success.

Knowledge management has been studied through numerous theories and reflections by various eminent scientists who have researched throughout history how the success of an organisation is achieved through management, and one part of that management is precisely knowledge. According to Dimitrovski [4] knowledge management can be defined as maximising the use of knowledge in an organisation, recognising information, and strengthening the capabilities and competitiveness of the organisation itself which significantly contributes to the success of the organisation. Another definition of knowledge management is that it is a series of processes of collecting, organising, analysing and disseminating the knowledge of individuals and groups throughout the organisation so that these processes contribute to business success [5]. With the development of technology and the increased dynamism of 
society, knowledge today is growing at a rate that was once unimaginable. Management that strives to be competitive must adapt to today's conditions. Sustainable competitive advantage can only be created by strengthening the influence and using the collective knowledge bases of the organization, creating and strengthening the learning organization and generally putting knowledge at the center of business and its strategy [6].

Knowledge management is much more than just gathering knowledge; it focuses on enabling the employees of a particular organisation to have access to information so that they can use this information in the performance of their daily tasks and thus contribute to the goals of the organisation. According to Alfirević et al. [7] holds that knowledge management is the art of creating value from organizational intangible assets, while Singh and Anand [8] believe that knowledge management is explicit and systematic management of key knowledge and processes of its creation, collection, organization, diffusion, use and exploitation Wiig (1997), according to Alfirević et al. [7] defines knowledge management as an activity aimed at understanding, focusing and managing the systematic, explicit and thoughtful construction, renewal and application of knowledge. According to the same author, it is a set of clear and well-defined approaches and processes, with the ultimate goal of maximizing knowledge-based organizational effectiveness, as well as the return from organizational cognitive assets (KA), as well as its constant renewal. Knowledge management processes, according to Stipanović [8], are the identification of knowledge, acquisition of knowledge, development of knowledge, dissemination of knowledge and implementation of knowledge. Knowledge management today is treated as a process in which not only the benefits of the organisation's knowledge are maximised, but also the organisation's ability to contribute to the achievement of goals with that knowledge. Therefore, knowledge management is recognised as a means by which to achieve the organisation's mission and goals. Knowledge management is also focused on two specific business directions, namely, people-oriented and information-oriented. Organisations that use knowledge management are more focused on adopting the changes that result from today's society, but also on improving procedures, skills and human resources. By using this type of management as a business strategy, it is possible to enable a more straightforward and better flow of ideas, faster innovation, time optimisation, service improvement, tax revenues increase due to faster trade, costs reduction due to source information, elimination of redundancy, and many more [4].

\section{THE LEARNING ORGANISATION CONCEPT}

A learning organisation is a modern concept of an organisation's activity that responds to ever-growing changes in the environment and constant processes of globalisation, integration, mass supply and accessibility that motivate organisations to continue learning. By learning, the companies can compete specifically and in the long run and not just through marketing sales strategies and differentiation. Next to the "learning organisation" term, the notion of a "knowledge-creating organisation" can also be found in the professional literature. The concept of an organization learning its development began in the middle of the last century, but it has been the focus of the profession and society in general only for the last ten to fifteen years. Peter Senge made the greatest contribution to this in his book The Fifth Discipline. He points out that a knowledge-based organization is continuously adapting to changes in the environment precisely on the basis of gathering information, researching learning about change. The mentioned trends are related to the advancement of technology, the need to protect the environment and human health, globalization, strengthening the gap between developed and underdeveloped economies and integration, which makes some systems extremely turbulent [7]. It applies to organisations that create their solutions based on learning from practice and innovation. It can be said that knowledge and investing in employees and their knowledge, in general, has become the investment with the most prolonged returns. It can nevertheless be said that it is an organisation that strives to create its future with the help of learning as a continuous variable leading to that goal. According to Sikavica [11], learning organizations manage change because they have certain skills and value systems that include:

1) Skill of motivating for changes:

- Creating readiness for change,

- Neutralization of possible resistance to change.

2) Creating a vision:

- Clear ideology and values and set goals,

- Anticipation and pictorial perception of the future.

3) Developing political support:

- Assessment of the strength of the change agent,

- Identification of key stakeholders,

- Influencing stakeholders.

4) Transition management:

- Activity planning,

- Commitment planning,

- Management organizations and structures.

5) Preservation of the continuity of the ascending path of growth and development:

- Providing resources for change,

- Building a support system for change agents,

- Development of new competencies and skills,

- Establishment of new forms of action and behaviour,

- Maintaining the direction and trajectory of the goals.

Communication is crucial in any organization, and especially in learning because it is the basis of knowledge transfer [12]. Communication of a learning organization must not have noises, vague or ambiguous messages, etc. According to Lončarević [13] communication and style is necessary for:

1) Setting and realization of goals,

2) Making plans for the realization of goals,

3) Effective and efficient allocation of organization's resources,

4) Selection and evaluation of members of the organization, 
5) Leading, directing, motivating and creating a motivating climate as well

6) Control over the realization of the organization's goals.

The most important thing to point out is that the learning organisation concept does not differentiate hierarchical levels because they do not exist for the exchange of knowledge. A learning organisation is an organisation in which knowledge circulates without any obstacles. It creates a precondition for the progress, development and selfrealisation of employees, which contributes to the management and personnel management. A learning organisation continuously learns, which gives it the flexibility to adapt to change and in that lies its contribution to sustainable business through adapting to demand-based learning [14]. It is essential to point out that a learning organisation does not segment knowledge by individuals because as such, it has no particular purpose. In an organisation that learns, knowledge is dynamic, moving and exchanging and enriched continuously, with the understandings of each of the stakeholders of the organisation, experiences and practices. Once acquired, knowledge is continuously transformed into new ones. Hence the synergistic effects of the learning organisation. Learning takes place in all dimensions of the organisation, at all levels, through teams and individuals and circuits through the company's information system.

The transformation of an organisation into a learning one requires leadership that understands the concept and has a vision of transformation, is aware of the shortcomings of the existing organisation and recognises vital aspects that must be restructured first for a successful implementation of the learning organisation (i.e. the transformation of a traditional organisation into learning organisation [15]. The implementation of the learning organisation concept is not a one-time event, but instead, after the adoption of its values and principles, the restructuring and a continuous process of adjustment, i.e. change management, begins. Adapting to change is necessary because markets, needs, customers, technologies, regulations and even knowledge or the need for it are changing. The learning organisation monitors the changes, and following the possibilities, goals and benefits of the changes, it adapts to them or strives to find an optimal solution. The human resources management in the companies based on knowledge requires a remodelling of basic sub functions of human resources management as the managers will deal more often with people who decide themselves about their aims, who motivate themselves, organize and control [16]. Such employees are called knowledge workers. According to Lendzion [17] the term "knowledge worker" refers to a high class specialist who has unique knowledge and competencies. The appearance of knowledge workers in the organizational structure led to an evolution of human resources management basis towards such values as: competencies, knowledge and intellectual capital. There is definition of knowledge workers [16]:

1) They have a high level of specialist knowledge, education, experience and creation, dissemination or practical usage of knowledge are the most important aims of their work;

2) They can have a high level of abstract, low level of routine and are characterized by a constant need to update their knowledge;

3) They show a need for autonomy, trust, evaluation of work, they need to understand a context and to learn by experience; they understand the need of exchanging ideas with experts. Organizations that value their employees for what they know, and reward employees for sharing that knowledge create a climate that is more conducive to knowledge management. Organizations that enjoy knowledge superiority today may find themselves at a competitive disadvantage in the future if their competitors are more capable of learning within similar domains [18].

\section{RESEARCH METHODOLOGY}

In order to investigate the importance of a learning organisation as an organisational form, a survey was conducted in the spring of 2020. The respondents were employees of companies operating in the retail sector of Croatian retail chains. Empirical research focused on the exploration of personal attitudes and views of employees about the learning organisation concept. The questionnaire included certain statements being presented to the respondents that they needed to confirm in full (grade 5) or completely refute (grade 1). Since this would limit the respondent's replies between two extremes, a scaling between these extremes was introduced too (grades 2, 3 and 4 ) which allow conditional confirmation (4) or conditional refuting (2) and neutrality - neither true nor false (grade 3).

The demographic composition of employees showed a slightly higher share of female respondents (54\%), which is not surprising if we consider the fact that in the general structure of employees, due to the characteristics of the industry and labour market trends, female employees are predominant. A relatively equal share of both sexes in the sample allows for sample stability and testing of gender impact on the characteristics of the learning organisation.

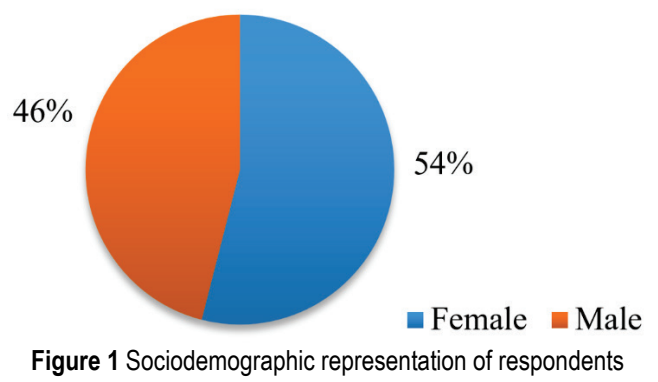

Given that the retail network dominates the structure of the organisation, the educational structure of employees is dominated by secondary education in (37\%). The secondary education level is followed by higher education with a share of $34 \%$, which is made by employees in retail support functions such as assortment, marketing and sales 
management. The survey sought to unify the sample's education structure to obtain the most realistic perception possible of employees regarding the learning organisation concept. The share of respondents with a university degree is quite substantial, too $-29 \%$. This share consists mostly of younger employees in the positions of individual functions' heads (marketing, finance, accounting, ICT, etc.) and assistants, independent clerks and directors. The age structure indicates that the average age of the respondents is 3.39 , which means in the age class from 34 to 41 years of age, i.e. about 38 years of age on average. The lowest share of respondents is of those up to 25 years of age, with a share of $14 \%$. The largest share of employees is between the ages of 42 and 49. Age is an interesting variable in the analysis of the learning organisation-related topics because it can indicate employee behaviour and preferences over time when it comes to the willingness to learn. The correlation test indicated a statistically significant and positive link, meaning that older employees (as a result of broader experience) have a higher motivation for acquiring new knowledge because it is easier for them to gain and extend it. This is mostly true for professions like accounting and finance, and less so for the retail and supply chain itself.

Along with the employee's age, the length of service is also an essential variable, both the total length of service and the duration of employment with the current employer. The average length of service is 15 years, while the length of service with the current employer is 12,5 years indicating a low fluctuation rate. This is a good starting point for establishing the learning organisation practices because obviously, employees are retained through specific values and qualities that need to strengthen by providing development and progress to employees through learning.

Table 1 Average values of age and length of service of respondents

\begin{tabular}{|l|l|r|r|r|}
\hline & & Age & Length of service & $\begin{array}{c}\text { Work experience in the } \\
\text { current organisation }\end{array}$ \\
\hline \multirow{2}{*}{$\mathrm{N}$} & Valid & 100 & 100 & 100 \\
\cline { 2 - 5 } & Missing & 1 & 1 & 1 \\
\hline Mean & 3.39 & 3.09 & 2.52 \\
\hline Mode & 4 & 4 & 1 \\
\hline \multicolumn{2}{l|}{ Minimum } & 1 & 1 & 5 \\
\hline \multicolumn{2}{l|}{ Maximum } & 6 & 7 & \\
\hline
\end{tabular}

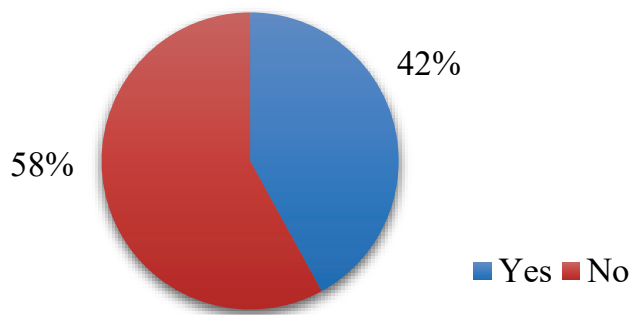

Figure 2 The structure of employees according to whether they were on an additional form of learning, acquiring new skills or training

The first indicator of specific organisation's orientation towards the learning organisation's concept of is how many types of training, seminars, further education or similar broadening of knowledge or strengthening the practice, have been attended by employees, regardless of the employment itself. Fig. 2 shows that $42 \%$ of employees had such experience, which indicates a lack of refresher courses improving the knowledge and skills of employees, especially in the retail segment, i.e. employees in the retail network (branch employees). Mostly, employees who are referred to additional forms of training, learning and further education are employees in managerial positions, and employees in support functions like finance, accounting, marketing, ICT and corporate communications.

When asked about the exchange of knowledge within the organisation, over $55 \%$ of employees stated that they do not see the continuity of such processes in the form of practice or within the value system. About $43 \%$ expressed the view that they notice the exchange of knowledge and experiences. The degree and presence of exchange and transfer of knowledge and experience vary from sector to sector and from department to department, which is determined by many factors. These factors do not represent as much the values of the learning organisation, but more the independent contribution of employees and relationships they have developed with each other. A lower degree of exchange of knowledge and experience is present in the procurement segment, and a slightly higher is present in the system within retail. A possible cause is employee competitiveness. Although a competitive spirit is welcome, it should be resultoriented, not causing close-mindedness when it comes to learning and transferring knowledge and experience within the organisation. The separation of these two views on competition among employees is the responsibility of management, the human resources department and the strategy of the learning organisation. It is needed in order to change employee perception, value system and rules as well as motivation, management and rewarding regarding this topic and to make the learning organisation concept as successful as possible. The extent to which respondents are motivated to acquire new knowledge and skills, and to apply learning for understanding beyond the dry process of performing work tasks can be seen from their level of motivation to acquire new knowledge and skills, which is shown in the table below.

The level of their motivation to learn is 3.37 , with the most common grade being 5. This indicates employees' interest and motivation for learning, aimed at achieving higher commitment to the activities and goals of the organisation. The latter is an indicator of a promising outlook for implementing the learning organisation concept. The willingness of employees to learn indicates their value system and work motivation in the development and acquisition of new skills and knowledge. In the long run, this must be accompanied by opportunities for progress, income growth and other incentives, because otherwise there is a decrease in motivation and an increase in turnover rates when employees in which the organisation invests decide to leave it. In the long run, this creates the cost of recruitment, training, training and specialisation and retention of employees, and reduces the effect of these efforts concerning investing continuously and in all dimensions in existing employees. 
Employee development and growth with the development of the organisation has synergy effects in the long run and is the basis of sustainable business. The willingness of employees to learn indicates their value system and work motivation in the development and acquisition of new skills and knowledge. In the long run, this must be accompanied by opportunities for progress, income growth and other benefits, because otherwise there is a decrease in motivation and an increase in employee turnover rates, i.e. leaving of employees in which the organisation had invested resources. In the long run, this creates the cost of recruitment, training, specialisation and retention of employees. Furthermore, it reduces the effect of these efforts instead of investing continuously and in all dimensions in existing employees. Employee development and growth have synergy effects with the development of the organisation in the long run and is the basis of sustainable business.

An indicator of the tendencies of a learning organisation is visible in the degree of employee independence and frequency in investing their efforts to improve their knowledge and skills and master the job faster. This can be seen in the table below, which shows that the level of independence for acquiring new knowledge and research practice is only 2.42 with the most common level of 2 . It is important to note that there is a lack of transfer of knowledge and practice in the superior-subordinate relationship (average level 2.27 and the most common 2). It further causes the reduced motivation and independence of employees in the research of practice, learning and training. It also reduces employees' willingness to transfer their knowledge and skills and to participate in discussions aimed at improving the process and solving problems (average level of participation is 2.27). Most often, employees who are not formally in charge of this type of cooperation do not attempt to contribute to such processes.

Table 2 Average values of salary amount and degree of motivation for learning and acquiring new skills of respondents

\begin{tabular}{|l|l|r|r|}
\hline \multirow{2}{*}{} & & Salary amount & $\begin{array}{c}\text { Does it motivate you to learn and } \\
\text { acquire new skills? }\end{array}$ \\
\hline \multirow{2}{*}{$\mathrm{N}$} & Valid & 100 & \\
\cline { 2 - 5 } & Missing & 1 & 100 \\
\hline Mean & 4.12 & 1 \\
\hline Mode & 2 & 5.37 \\
\hline Minimum & 1 & \\
\hline \multicolumn{2}{|l}{ Maximum } & 11 & 1 \\
\hline
\end{tabular}

Table 3 Average values of process evaluation, level of knowledge and experience transfer and participation in discussions for business process improvement

\begin{tabular}{|c|c|c|c|c|c|c|c|}
\hline & & $\begin{array}{l}\text { How often do you study } \\
\text { and research on your own } \\
\text { to improve your } \\
\text { performance/ master the } \\
\text { work tasks? }\end{array}$ & $\begin{array}{l}\text { Is the quality of } \\
\text { business processes } \\
\text { being assessed? }\end{array}$ & $\begin{array}{l}\text { Do you participate in } \\
\text { discussions, meetings, } \\
\text { etc. with superiors to } \\
\text { improve the processes } \\
\text { and solve problems? }\end{array}$ & $\begin{array}{l}\text { Do superiors pass } \\
\text { on news and } \\
\text { changes and seek } \\
\text { to pass on new } \\
\text { practices? }\end{array}$ & $\begin{array}{c}\text { Does your } \\
\text { organisation } \\
\text { motivate and reward } \\
\text { teamwork, learning } \\
\text { and sharing of } \\
\text { experiences? } \\
\end{array}$ & $\begin{array}{l}\text { Do you often use } \\
\text { new technologies } \\
\text { in the business } \\
\text { processes in the } \\
\text { organisation? }\end{array}$ \\
\hline \multirow{2}{*}{$\mathrm{N}$} & Valid & 100 & 100 & 100 & 100 & 100 & 100 \\
\hline & Missing & 1 & 1 & 1 & 1 & 1 & 1 \\
\hline \multicolumn{2}{|c|}{ Mean } & 2.42 & 3.21 & 2.27 & 2.33 & 2.27 & 2.76 \\
\hline \multicolumn{2}{|c|}{ Mode } & 2 & 3 & 1 & 2 & 2 & 3 \\
\hline \multicolumn{2}{|c|}{ Minimum } & 1 & 1 & 1 & 1 & 1 & 1 \\
\hline \multicolumn{2}{|c|}{ Maximum } & 5 & 5 & 5 & 5 & 5 & 5 \\
\hline
\end{tabular}

Table 4 Average values of selected variables

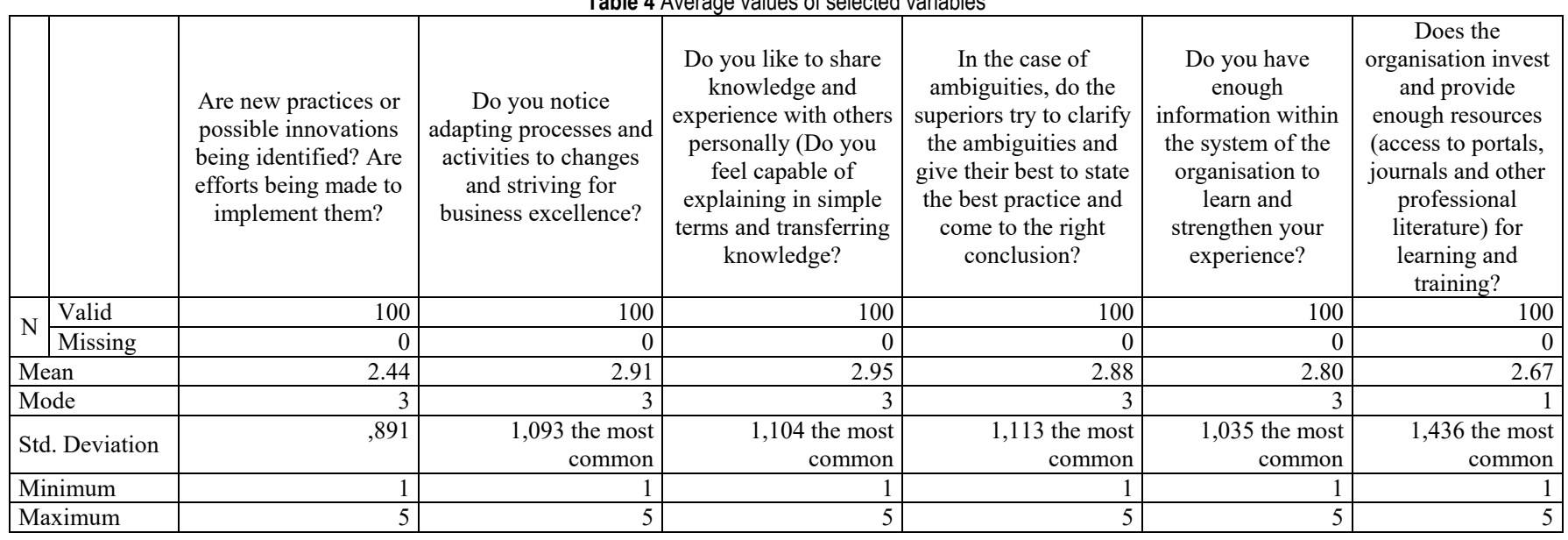

Although teamwork is necessary and impossible to avoid, the level of team cooperation, organisation and monitoring of team cooperation and team management as well as the exchange of knowledge and experiences between teams is not standard practice, because the level of such activities is only 2.27. A slightly higher level is observed in the monitoring and evaluation of the process of 3.21 .
However, this is not enough to realise its improvement in practice. The latter monitoring is only part of the formalisation and insight into work tasks and for job descriptions. Infrastructure is of crucial importance for success and practical application of the principles of the learning organisation, part of which is made of the information system and database, along with its use by 
employees, as well as new technologies that improve business processes. The degree of application of new technologies does not correspond to the possibilities and is only 2.76 . This is because many processes have not been automated (especially those outside the retail chain) as much as they could. Thus, the implementation of the new ERP system was postponed despite the division of the company and a significant larger acquisition. Savings today do not always mean the same expected return on a later investment. Delays in the implementation of ERP have been accompanied by several overtime hours (by ICT, technical services and accounting departments) and thus less efficiency. The limited-time led to less willingness of employees to share knowledge, to research independently and invest in new knowledge. They had less time they could devote to training new colleagues.
A significant link in a learning organisation is communication, style and communication strategy because it ultimately influences the realisation of business processes and enables the transfer of knowledge. Table 5 shows relatively medium and low ratings of clarity in communication and thus, the processes themselves. It is also clear that in situations of learning needs, superiors rarely declare that they do not understand or need the help of a colleague or external expert, which is not acceptable and creates barriers to communication. The unequal conversation leads to reduced quality of the process, which does not exceed the average level of 3. Nevertheless, on average, employees believe that the organisation is professional in its sector with an average score of 3.52 , which is only a perception in trade, not the quality of all organisational processes because it is challenging to cover all processes, especially in larger organisations.

Table 5 Average values of agreement with selected statements

\begin{tabular}{|c|c|c|c|c|c|c|c|}
\hline & & $\begin{array}{l}\text { Do you talk on an } \\
\text { equal footing with } \\
\text { colleagues, regardless } \\
\text { of the position they } \\
\text { hold, about business } \\
\text { issues? }\end{array}$ & $\begin{array}{l}\text { Have you encountered } \\
\text { a situation where a } \\
\text { superior declares that } \\
\text { he does not understand } \\
\text { something, and you } \\
\text { jointly seek the help of } \\
\text { a colleague at a higher } \\
\text { level or an external } \\
\text { expert? }\end{array}$ & $\begin{array}{l}\text { Is it a problem for } \\
\text { you to say that you } \\
\text { don't know } \\
\text { something and that } \\
\text { you need help? }\end{array}$ & $\begin{array}{l}\text { How would you rate } \\
\text { the clarity of the } \\
\text { business processes in } \\
\text { the organisation? }\end{array}$ & $\begin{array}{l}\text { How do you rate the } \\
\text { clarity of } \\
\text { communication with } \\
\text { superiors? }\end{array}$ & $\begin{array}{l}\text { How do you rate the } \\
\text { expertise of the } \\
\text { organisation, in the } \\
\text { industry in which it } \\
\text { operates? }\end{array}$ \\
\hline \multirow{2}{*}{$\mathrm{N}$} & Valid & 100 & 100 & 100 & 100 & 100 & 100 \\
\hline & Missing & 0 & 0 & 0 & 0 & 0 & 0 \\
\hline \multicolumn{2}{|c|}{ Mean } & 2.95 & 2.23 & 2.61 & 2.90 & 2.80 & 3.52 \\
\hline \multicolumn{2}{|c|}{ Mode } & 4 & 1 & 1 & 3 & 3 & 3 \\
\hline \multicolumn{2}{|c|}{ Std. Deviation } & $\begin{array}{r}1,424 \text { the most } \\
\text { common }\end{array}$ & $\begin{array}{r}1,162 \text { the most } \\
\text { common }\end{array}$ & $\begin{array}{r}1,456 \text { the most } \\
\text { common }\end{array}$ &, 893 & $\begin{array}{r}1,015 \text { the most } \\
\text { common }\end{array}$ &, 870 \\
\hline \multicolumn{2}{|c|}{ Minimum } & 1 & 1 & 1 & 1 & 1 & 2 \\
\hline \multicolumn{2}{|c|}{ Maximum } & 5 & 5 & 6 & 5 & 5 & \\
\hline
\end{tabular}

In the continuation of the research, the influence of gender on specific aspects of the learning organisation was tested. Given the empirical significance of the test, it is observed that statistically, there is a significant impact only in the case of motivation to learn and acquire new skills. The conclusion was made based on empirical significance, which is below the conditions of a maximum of $5 \%$ and amounts to $3.6 \%$.

Table 6 Mann-Whitney in a test of gender influence on selected variables

\begin{tabular}{|c|c|c|c|c|}
\hline & $\begin{array}{l}\text { Does learning and acquiring } \\
\text { new skills motivate you? }\end{array}$ & $\begin{array}{l}\text { Do you talk on an equal footing } \\
\text { with colleagues, regardless of } \\
\text { the position they hold, about } \\
\text { business issues? }\end{array}$ & $\begin{array}{c}\text { Is it a problem for you to say } \\
\text { that you don't know } \\
\text { something and that you need } \\
\text { help? }\end{array}$ & $\begin{array}{l}\text { Do you like to transfer knowledge } \\
\text { and experience to others } \\
\text { personally? (Do you feel capable } \\
\text { of explaining in simple terms and } \\
\text { transferring knowledge?) }\end{array}$ \\
\hline Mann-Whitney U & 947 & 1238 & 1051 & 1119 \\
\hline Wilcoxon W & 2028 & 2319 & 2132 & 2200 \\
\hline $\mathrm{Z}$ & $-2,092$ the most common & -0.028 & $-1,359$ the most common & -0.881 \\
\hline Asymp. Sig. (2-tailed) & 0.036 the most common & 0.977 & 0.174 the most common & 0.378 the most common \\
\hline
\end{tabular}

To find out which of the factors has an impact on motivation to learn and acquire new knowledge, the correlation between motivation to learn and opportunities to acquire new knowledge and education and the salary was investigated. Table 8 shows that the calculated correlation coefficients are statistically significant because the practical level of test significance is $0 \%$ for both correlation coefficients. Thus, it can be concluded that there is a statistically significant and even a strong relationship between learning motivation and opportunities to acquire new skills and salary levels because the correlation coefficient is 0.737 . This means that with the increase of personal income, the power of motivation of the opportunities for learning and acquiring new skills increase. Employees tend to feel valued and are thus more willing to learn and commit, so these opportunities also make them more motivated in general. The correlation coefficient of learning motivation and opportunities for acquiring new skills and education is 0.458 , which also indicates that higher motivation for learning and opportunities for acquiring new 
skills can be expected from employees with higher education. Such results indicate the connection between some elements of the organisational structure and human capital management. They also indicate their connection with the principles and the foundation on which the learning organisation concept is based. Dissatisfaction creates new dissatisfaction, which means that dissatisfied employees who feel underpaid or are in an unenviable environment in the company cannot be motivated to acquire new knowledge and skills if their basic needs of belonging to the organisation, self-realisation and existential needs (which are realised through their salary) are not met. A learning organisation has different values and goals from a profit-oriented organisation.

Table 7 Spearman correlation test between employees' motivation based on having opportunities for learning and acquiring new knowledge/skills and employees' education and salary

\begin{tabular}{|c|c|c|c|c|c|}
\hline & & & Qualifications & Salary amount & $\begin{array}{l}\text { Are you motivated by learning and } \\
\text { acquiring new skills? }\end{array}$ \\
\hline \multirow{9}{*}{ Spearman's rho } & \multirow{3}{*}{ Qualifications } & Correlation Coefficient & 1,000 &, $737 * *$ &, $458 * *$ \\
\hline & & Sig. (2-tailed) & &, 000 &, 000 \\
\hline & & $\mathrm{N}$ & 100 & 100 & 100 \\
\hline & \multirow{3}{*}{ Salary amount } & Correlation Coefficient & ,737** & 1,000 &, $567 * *$ \\
\hline & & Sig. (2-tailed) &, 000 & &, 000 \\
\hline & & $\mathrm{N}$ & 100 & 100 & 100 \\
\hline & \multirow{3}{*}{$\begin{array}{l}\text { Are you motivated by learning and } \\
\text { acquiring new skills? }\end{array}$} & Correlation Coefficient &, $458 * *$ &, $567 * *$ & 1,000 \\
\hline & & Sig. (2-tailed) &, 000 &, 000 & \\
\hline & & $\mathrm{N}$ & 100 & 100 & 100 \\
\hline
\end{tabular}

The importance of fundamental reorganisation of the organisation from the top to the process, the value system and rules and procedures is manifested in the fact that the state of consciousness, perception of and expectations from the learning organisation is crucial for the organisation's climate, motivation, management and acceptance of the change. Employees with a different view of the learning organisation concept and who are thus more motivated by learning than others, see changes both necessary and existing in the processes that are crucial for the implementation of the learning organisation concept. This is confirmed by the correlation of employees' preference for the transfer of knowledge and experience to colleagues and the ability to identify necessary and existing activities in organising the process of the organisation that makes it closer to the learning organisation concept.

Table 8 Spearman's test of correlation between employee's readiness to transfer their knowledge and experience to co-workers and their perception of process characteristics

\begin{tabular}{|c|c|c|c|c|}
\hline & & & $\begin{array}{l}\text { Do you notice processes and } \\
\text { activities adapting to changes and } \\
\text { striving for business excellence? }\end{array}$ & $\begin{array}{l}\text { Do you like to transfer } \\
\text { knowledge and experience to } \\
\text { others personally? (Do you feel } \\
\text { capable of explaining in simple } \\
\text { terms and transferring } \\
\text { knowledge?) }\end{array}$ \\
\hline \multirow{6}{*}{ Spearman's Rho } & \multirow{3}{*}{$\begin{array}{l}\text { Do you notice processes and activities } \\
\text { adapting to changes and striving for } \\
\text { business excellence? }\end{array}$} & Correlation Coefficient & 1 &, $469 * *$ \\
\hline & & Sig. (2-tailed) & & 0 \\
\hline & & $\mathrm{N}$ & 100 & 100 \\
\hline & \multirow{3}{*}{$\begin{array}{l}\text { Do you like to transfer knowledge and } \\
\text { experience to others personally? (Do } \\
\text { you feel capable of explaining in } \\
\text { simple terms and transferring } \\
\text { knowledge?) }\end{array}$} & Correlation Coefficient &, $469 * *$ & 1 \\
\hline & & Sig. (2-tailed) & 0 & \\
\hline & & $\mathrm{N}$ & 100 & 100 \\
\hline
\end{tabular}

Finally, from this aspect, the perception of employees regarding the organisation to which they currently belong was explored. It was observed that only $9 \%$ of respondents believe that their existing organisation has some features of a learning organisation and a sound basis for development in this direction in the future. The fact that it has been observed that there are no favourable prospects in the researched organisations' existing foundations is undoubtedly a shortcoming that will lead to more significant efforts and the risk of deviating from the successful implementation of the concept of the learning organisation. Indeed, organisations must not be rigid and inflexible because the learning organisation changes in line with learning aimed at sustainability and development. Therefore, as such, it cannot be immutable but dynamic and consistent with typical principles of operation.
The results of the research showed that no organisation is, in the full and literal sense, a learning organisation because even this concept is not stable for the entire duration of the organisation. The key lies in the awareness, values of the organisation and motivation for learning, what does not always necessarily mean the highest level of knowledge and the current ability to absorb it. The development of technologies and changes in learning goals can make an organisation a learning organisation in certain aspects and to a reduced extent. The concept of a learning organisation must be embedded in the value system and mission of the company. It is also vital that the company develops skills to continually build and maintain processes on the level of a learning organisation. 


\section{CONCLUSION}

Information and knowledge have never been more accessible, but it is also an increasingly depreciating variable, i.e. a flow variable whose level requires constant investment because it decreases over time. Organisations have become aware of the importance of lifelong learning, i.e. learning organisations concept, so they are increasingly turning to this concept of business. Investments in knowledge, development and innovation are the investments with the highest return through business sustainability and a better perspective. The accelerating development and the need to implement new technologies encourage organisations to change and learn. This is the cause for the learning organisation becoming a way organisation operates, not just an alternative behaviour and concept of business.

On the other hand, new technologies require constant learning to apply and use them within the organisational process. A study of the presence of the learning organisation concept in selected models indicated that this system is still not recognised in Croatian companies. The most significant disadvantage is insufficient investment in strengthening the knowledge of employees and non-participation and communication within the organisation. The advantages and perspectives for the implementation of the learning organisation concept lie within the experience and knowledge of the sector in which they operate and its employees. This is especially relevant in maintaining databases and channels for the implementation of learning processes along with the knowledge base management. The entire knowledge management process affects the improvement of employees' experience and skills, the processes within the organisation, but also the performance of daily tasks and reducing the shortcomings of the organisation. Knowledge management appears as a process carried out by the management of the company. It helps the company in the dissemination of the professional know-how and essential information that contribute to the company goals. Therefore, knowledge management, within the modern business operations of a company, is viewed as an important factor for increasing the competitiveness of Croatian companies.

\section{REFERENCES}

[1] Klindžić, M. \& Galetić, L. (2015). Organizacijsko učenje kao izvor konkurentske prednosti - stvaranje konteksta za potporu organizacijskom učenju: Ekonomski pregled. Hrvatsko društvo ekonomista. Zagreb. 66 (1), 3-30.

[2] North, K. (2008). Upravljanje znanjem: vođenje poduzeća usmjereno prema znanju: Naklada Slap. Jastrebarsko.

[3] Dimitrovski, R. (2010). Menadžment znanja kao poslovna strategija. Škola Biznisa. Retriwed from https://www.researchgate.net/publication/309428487 MENA DZMENT ZNANJA KAO POSLOVNA STRATEGIJA

[4] Mazur, M., Spahić, A.; Grabar, D., Grd, P., Sedlbaurer, G., Sikorska, K., \& Pallarés Beamonte, E. (2014). Upravljanje znanjem - priručnik za poduzeća: Lifelong Learning Programme, Zagreb.

[5] Bahtijarević-Šiber, F. (2014). Strateški menadžment ljudskih potencijala: Suvremeni trendovi i izazovi: Školska knjiga. Zagreb.
[6] Alfirević, N., Praničević, G., \& Talaja, A. (2014). Upravljanje organizacijskim promjenama $i$ znanjem: Ekonomski fakultet Sveučilišta u Splitu. Split.

[7] Anand, A. \& Singh, M. D. (2011). Understanding Knowledge Management: a literature review. International Journal of Engineering Science and Technology (IJEST), 3(2), 932-934. Retriwed from: https://www.ajol.info/index.php/ijest

[8] Wiig, K. M. (1997). Knowledge Management: An Introduction and Perspective: Journal of Knowledge Management 1(1), 1215. https://doi.org/10.1108/13673279710800682

[9] Stipanović, C. (2009). Poslovna inteligencija u turizmu. Fakultet za menadžment u turizmu i ugostiteljstvu, Opatija.

[10] Galić, M. (2010). Učeće organizacije. MediAnali, 4(7), Sveučilište u Dubrovniku. 179-182. Retriwed from: https://hrcak.srce.hr/55361

[11] Sikavica, P. (2011). Organizacija. Školska knjiga. Zagreb.

[12] Rouse, M. J. \& Rouse, S. (2005). Poslovne komunikacije. Masmedia. Zagreb.

[13] Lončarević, R. (2007). Menadžment. Univerzitet Singidunum. Beograd.

[14] Rupčić, N. \& Žic, M. (2012). Upravljanje znanjem - suvremena sržna kompetencija. Praktični menadžment, 3(2), 21-28. Retriwed from: https://hrcak.srce.hr/96977

[15] Lamza - Maronić, M., Glavaš, J., \& Lepešić, D. (2009). Poslovni informacijski sustavi - podloga suvremenom poslovanju. Ekonomski fakultet u Osijeku. Osijek.

[16] Davenport, T. H. (2007). The Managing of Knowledge Workers. Walters Kluwer. Polska. 16-18. https://doi.org/10.4324/9780080492735-4

[17] Lendzion, J. P. (2015). Human Resources Management in the System of Organizational Knowledge Management. Procedia Manufacturing, 3, 677-678. https://doi.org/10.1016/j.promfg.2015.07.303

[18] McKeen, J. D., Zack, M. H., \& Singh, S. (2006). Knowledge Management and Organizational Performance: An Exploratory Survey. HICSS '06: Proceedings of the $39^{\text {th }}$ Annual Hawaii International Conference on System Sciences - Vol. 08. IEEE Computer Society, NW Washington, United States. https://doi.org/10.1109/HICSS.2006.242

\section{Authors' contacts:}

Andreja Rudančić, PhD, Assistant professor

(Corresponding author)

Libertas International University,

Trg J. F. Kennedya 6b, 10000 Zagreb, Croatia

E-mail: arudancic@libertas.hr

Petar Mišević, PhD, Assistant professor

University North,

Trg dr. Žarka Dolinara 1, 48000 Koprivnica, Croatia

E-mail: pmisevic@unin.hr

Dušan Tomašević, MSc

Libertas International University,

Trg J. F. Kennedya 6b, 10000 Zagreb, Croatia

E-mail: dtomasevic@libertas.hr 